Journal of Community Based Environmental Engineering and Management, 2021, Vol. 5, No. 2: 117-124

\title{
KNOWLEDGE SHARING OF OCCUPATIONAL HEALTH AND SAFETY IN MINING AT PT. PILAR ARTHA SEJAHTERA, LAMPUNG
}

\author{
Reza Aryanto ${ }^{1}$, Edy Jamal Tuheteru ${ }^{1 *}$, Prayang Sunny Yulia $^{2}$, Syamidi Patian ${ }^{1}$ \\ ${ }^{1)}$ Department of Mining Engineering, Faculty of Earth and Energy Technology, Universitas Trisakti, \\ Indonesia \\ ${ }^{2)}$ Department of Petroleum Engineering, Faculty of Earth and Energy Technology, Universitas Trisakti, \\ Indonesia
}

\begin{abstract}
Mining activities in general are high risk and high financing activities. One of the risks that are of concern to mining activities is related to occupational health and safety (OHS). The importance of OHS for the mining industry, the Community Service (CS) team of the Faculty of Earth and Energy Technology conducted counseling activities and discussions on the importance of the implementation of OHS in the field of mining. OHS counseling is done at Pillar Artha Sejahtera Company which is one of the smallscale mining industries that conduct andesite stone mining with a quarry system located in Lampung. Participants in this CS activity in addition to the team consisting of lecturers and employees and also followed by employees and leaders of PAS Company. CS activities are carried out by the method of exposure of material by the team which was previously preceded by field survey activities conducted by the CS team and furthermore is a discussion activity. Based on the discussions that developed during the activity, employees and leaders of PAS Company appreciates and is very grateful for the implementation of CS activities, because through this activity there is a refreshment of understanding and deepening of OHS material that has been an integral part of PAS Company. PAS Company hopes that activities like this should continue to be carried out, even not only for CS activities, it can also be for teaching and research activities.
\end{abstract}

Keywords: Knowledge Sharing, Occupational Health and Safety, Pillar Artha Sejahtera Company

\section{Introduction}

Occupational health and safety (OHS) is an important part of the mining industry (Atmaja \& Palimbong, 2020). OHS aspects are included in the rules of good and correct mining (Ministry of Energy and Mineral Resources, 2018). PAS Company is one of the mining industries that will not be free from potential accidents and

\footnotetext{
${ }^{*}$ E-mail: ejtuheteru@ trisakti.ac.id
}

Received: 2 September 2021

Revised: 16 September 2021

Accepted: 18 September 2021

DOI: $10.23969 /$ jcbeem.v5i2.4532 potential health problems, especially for employees in the field. Characterization of the potential that can arise due to mining activities even in a small scope of work must always be done, by doing so, preventive measures can be taken to avoid accidents. Understanding and refreshment of OHS must be done by following the rules and regulations that have been set by both the local government and the central government. In addition to following the existing rules, it is expected that there is also good cooperation with parties who can provide OHS refreshment for employees and company 
leaders. So that OHS activities are not only an obligation but have become part of the pulse of the mining industry (Prakoso et al., 2021).

This Community Service (CS) activity is carried out with the aim to provide refreshment of understanding and deepening of the importance of attention to occupational health and safety in the mining industry. With this activity, it can increase good cooperation between college institutions and the mining industry as a form of link and mach activities. Cooperation made not only through community service activities can also be improved by teaching activities such as field trips and also research activities to help the mining industry in solving problems faced in the field.

\section{Research Methodology}

CS activities are carried out at Pilar Artha Sejahtera Company (PAS Company) which is one of the mining companies that do andesite stone mining with quarry mining system. PAS Company is one of the mining companies that include the middle. PAS Company is located in Lampung Province. Established in 2016, PAS Company supporting in the process of building the trans Sumater toll road starting from Bakauheni to Palembang. Mining activities conducted in PAS Company ranging from mining activities to processing activities, namely the reduction of rock size in accordance with orders from consumers, as seen in Figure 1. The main products are Split Material 1-2 (size 1-2 $\mathrm{cm}$ ), Split Material 2-3 (size 2-3 cm), screening material (size $0.5-1 \mathrm{~cm}$ ), and stone ash material (size $0.1-0.5 \mathrm{~cm}$ ).

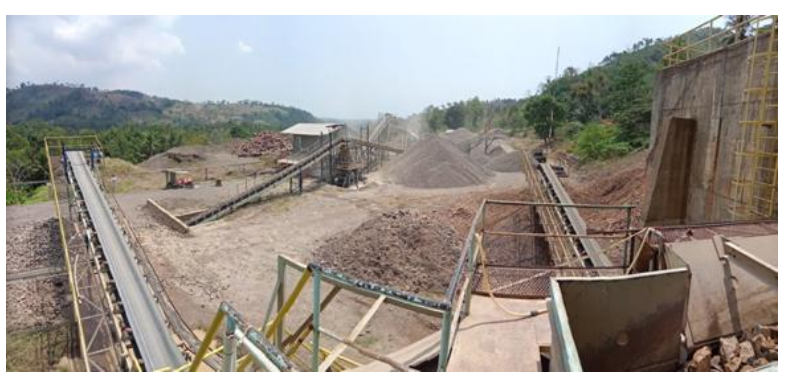

Figure 1. Operational Activities in PAS Comp.

CS activities begin by conducting a survey to PAS Company to get an overview of the condition of mining operations directly in the field. This activity is also to see firsthand what potential affects occupational health and safety for employees. In addition to seeing directly, there are also interviews with several employees and company leaders. The delivery of field conditions was delivered by the deputy Head of Mining Engineering.

This form of CS activity is exposure to material by the team. The delivery of material is delivered through zoom media, because in the condition of the Covid-19 pandemic, so it cannot be done directly. The material submitted is a policy related to OHS mining, OHS management, the actual condition of the number of accidents in the mining field. Exposure is delivered in the form of interesting images in order to get the attention of the response from the participants. In addition to the form of images, it is also delivered in the form of graphics to increase the awareness of the participants, to maintain occupational health and safety in the place where employees perform activities. After exposure by the CS team, continued with discussion activities, so that participants get a thorough understanding of the importance of the implementation of OHS in the field of mining and can be applied in their respective workplaces. 


\section{Result and Discussion}

Participants of CS activities are teams consisting of lecturers and Faculty of Earth and Energy Technology employees, employees and leaders of PAS Company with the number of participants as many as 16 people seen in Figure

2. The CS activities began with a preliminary speech delivered by the CS Team Leader, who conveyed the purpose of this Community Service activity. The purpose of CS is to provide an overview to employees at PAS Company on the importance of paying attention to occupational health and safety in the field of mining. One thing that needs to be realized is that if you do not pay attention to OHS activities and there is an accident, then the sanctions can be up to the closure of mining operations. Next is to get a welcome from the Head of Mining Engineering PAS Company, conveyed that CS activity is highly appreciated, because with this activity, it can provide refreshment to leaders and employees who are constantly reminded about the importance of OHS in the field of mining.

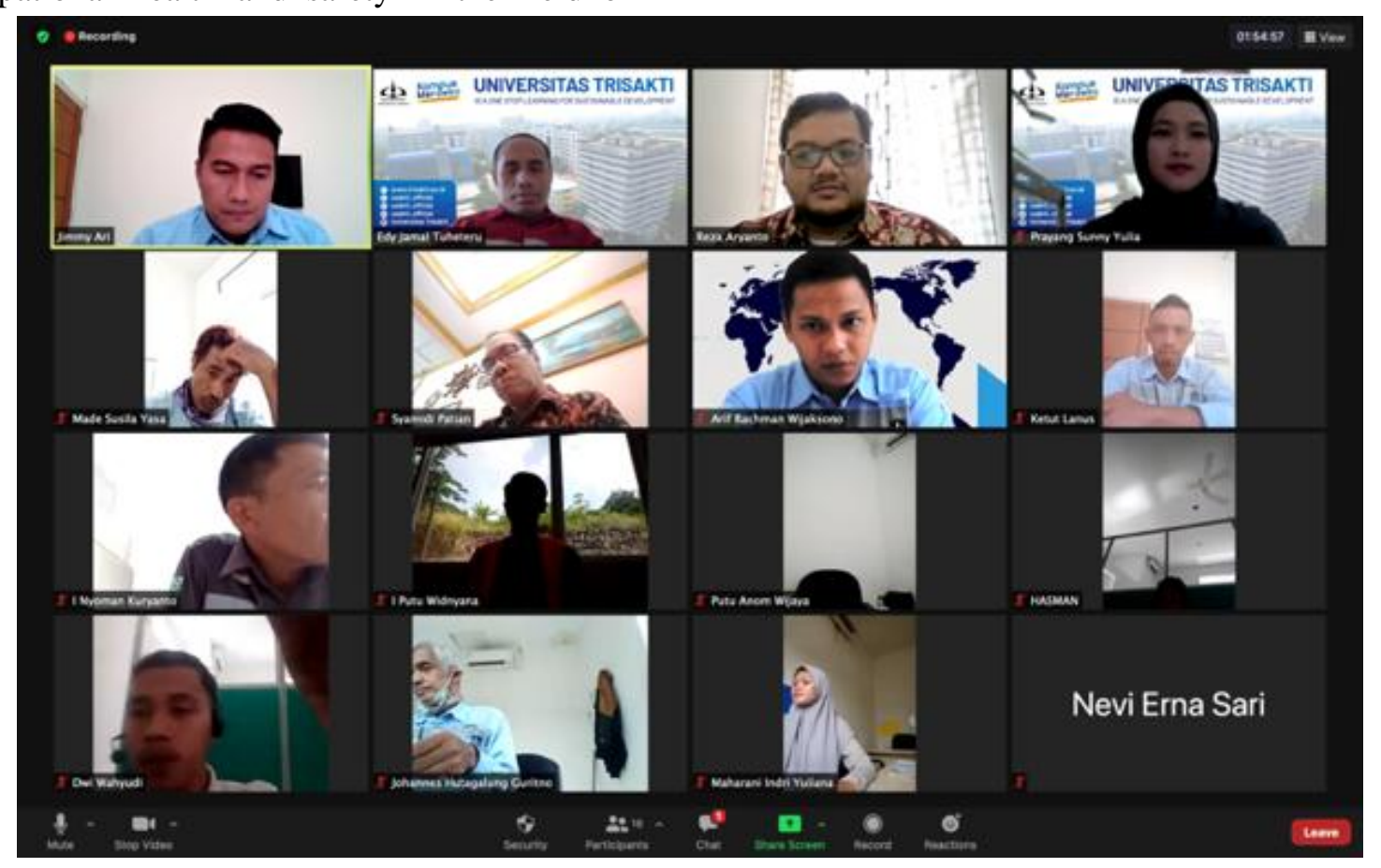

Figure 2. Community Service Participants

In Figure 3, the head of PAS Company presented the material as an introduction to PAS Company to the CS team. The exposure delivered is history, mining operations, activities of suing or reducing the size to the marketing process. Head of PAS Company also reminded the importance of good mining practice rules in mining activities whose contents are: (1) Licensing and legality of mining companies, (2) Exploration systems, (3) Mining feasibility studies, (4) Conducting mining activities, (5)
Good and planned processing of mining materials, (6) OHS aspects, (7) Environmental aspects, (8) Human rights aspects or rights of the surrounding community, and (9) Aspects of mine closure or post-mine continuity. Based on the Good Mining Practice, it is emphasized how to conduct mining operations that always pay attention to aspects of OHS.

The presentation delivered by the CS Team consists of 3 materials namely OHS Management in the Mining Industry, Occupational 
Health and Safety Practices in the Mining Industry, and the last is material on the application of 5S (Seiri, Seiton, Seiso, Seiketsu and Shitsuke) and Hourensou as seen in Figure 3. At the OHS Management meteri in the mining industry delivered several explanations about occupational health and safety, mining safety and mining occupational health and safety. Occupational health and safety are conditions and factors that impact, or can have an impact on, the health and safety of employees or other workers (including contract workers \& contractor personnel, or others at work) (OHS Management Systems, 2007). Mining safety is all activities including the management of safety and health of mining work and the safety of mining operations, then the meaning of safety and health of mining work is all activities to ensure and protect workers to be safe and healthy through efforts to manage work safety, occupational health, work environment and occupational safety and health management system (Directorate General of MINERBA, 2019).

It is also conveyed that the purpose of work safety is to prevent/take precautions so that workers/employees do not get injured/harm and also there is no damage or loss of equipment /materials or production. While the factors that need to be mined in work safety are: humans, machines, materials, working methods, and the work environment. Strengthening awareness that OHS activities are something regulated by the government, it is also conveyed the legal basis of OHS.

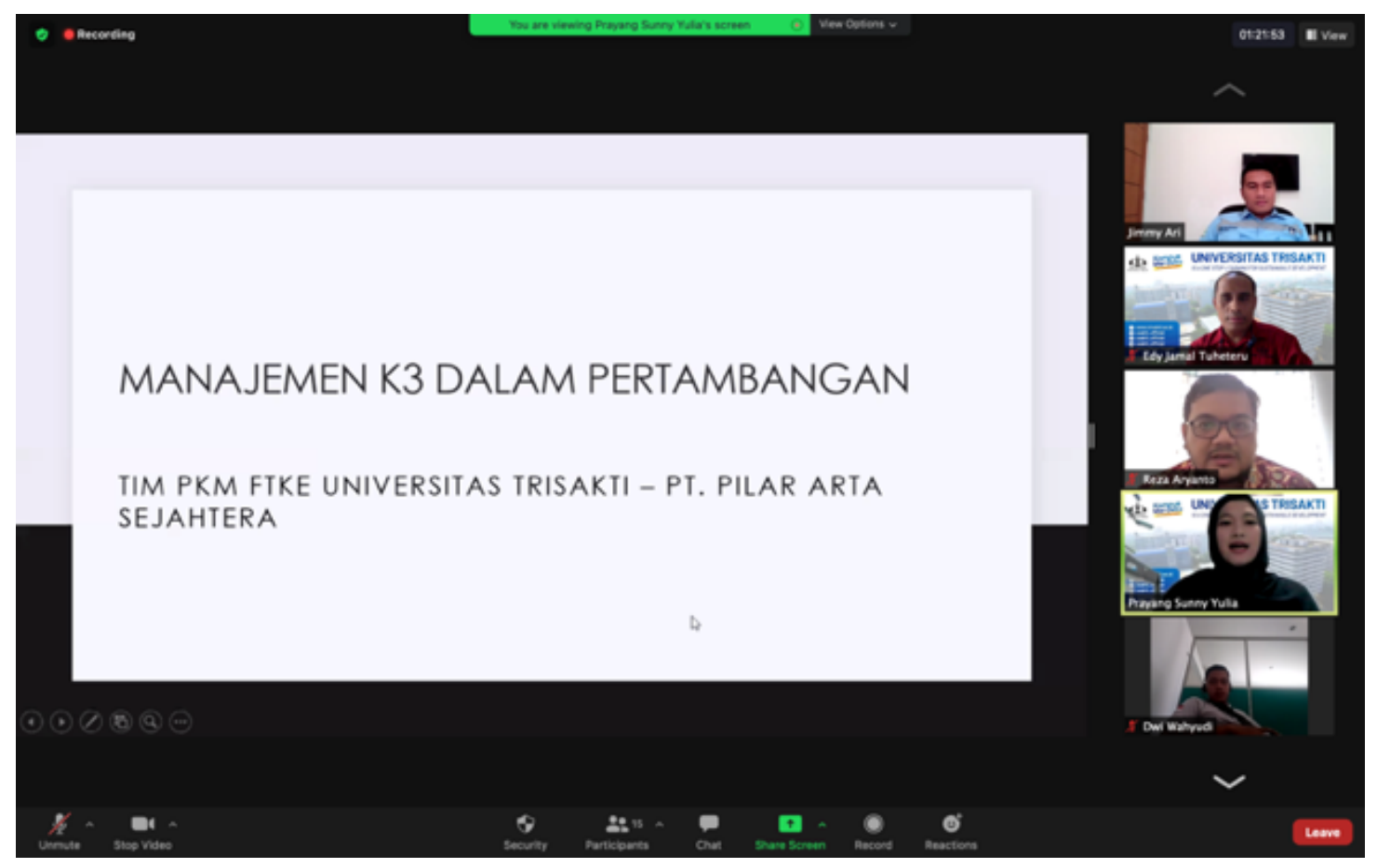

Figure 3. Explanation of Material by CS Team

There are legal bases used related to good mining rules. Law No. 3 of 2020 on Amendments to Law No. 4 of 2009 on mineral and coal mining, the relevant regulations are the
Decree of the Minister of Energy and Mineral Resources No. 1827K/30/MEM/2018, Decree of the Minister of Energy and Mineral Resources No. 26 of 2018 on the implementation of good 
mining rules and supervision of mineral and coal mining, and Decree of the Director General of Minerals and Coal No. 185/30/DJB/2019 on instructions for mining safety implementation techniques and implementation, assessment and reporting of Mineral and coal Mining Safety Management System.

An understanding of the work safety measures that employees need to take is very important to know. This activity provided an overview of the steps in occupational safety, including: (1) Knowing the work to be done, (2) Understanding the steps/stages of the work, (3) Knowing the dangers that may occur from the work to be done, and (4) Knowing how to control the dangers. In addition, it is also explained about the benefits obtained if you can do good work safety, including: (1) Saving the family from: sadness/diffculties, an uncertain future, and loss of income/livelihood. (2) Saving employees from: Pain/disability, Loss of time, Sadness, Loss of the future, and Loss of income/livelihood and (3) Saves the company from: Loss of labor, expenses due to accidents, training or replacing injured employees, loss of time due to delayed activities and decreased production, may even stop production.

In mining operations, the importance of employees having good health in carrying out their activities in the company. So the team explained the purpose of occupational health is to protect workers from everything that can harm health due to work. It is also important to have health checks for employees. A health check is carried out on: (i) the new worker, to determine the overall initial condition of the new employee; (ii) Long-time workers, in order to monitor health/diseases that may arise as a result of the work performed; and (iii) Health checks are periodically conducted every: at least once every 6 months for underground mine employees and at least once a year for mine employees on the surface. Sources that affect the work environment generally come from dust, noise, lighting, vibrations and toxic gases.

OHS's succeed in mining can occur by continuing to do OHS coaching for employees. Efforts that can be done to achieve OHS well, through: (1) counseling, Lectures on OHS, Installation of OHS posters and Screening of films/slides about OHS; (2) safety talk, conducted at each shift, discussing what is done, what risks, what equipment should be used, and hazard handling; (3) Safety training, training on how to use work safety equipment; (4) Safety Inspection: Unplanned inspection and planned inspection (general and periodic observation /inspection); (5) Safety Investigation, Safety Meeting, Environmental Monitoring of Working Conditions, OHS Organization; (6) Provision of OHS Equipment; and (7) Annual OHS Programs, including: OHS Observation Training Program, Job Safety Analysis (JSA) Program, Planned OHS Inspection, Joint Inspection, and Meetings.

On exposure to OHS practices in mining activities, some accident data has been submitted in mining activities. Based on mining accident data released by the directorate general of minerals and coal in 2021 as seen in Figure 4 (Directorate of Engineering and Environment Directorate General of Mineral and Coal, 2020). Mine accident data submitted from 2015 to 2020 with the category of light, heavy and dead. Based on the data, it is seen that the highest light accident data occurred in 2017 with the number of accidents at 62 incidents, the lowest in 2020 with the number of 33 incidents, while in 2015, 2016, 2018 and 2019 were 52, 59, 47 and 49. Accidents with the highest heavy category in 2019 amounted to 105 incidents and the lowest occurred in 52 incidents. In 2015, 2016, 2017 and 2020, there were 78, 71, 94 and 95 incidents. While the accidents that caused the 
highest death occurred in 2015 as many as 25 incidents and the lowest occurred in 2018 and 2017, which was 11 accidents, for 2016, 2018, 2019 and 2020 were 16, 17, 24 and 17 incidents.

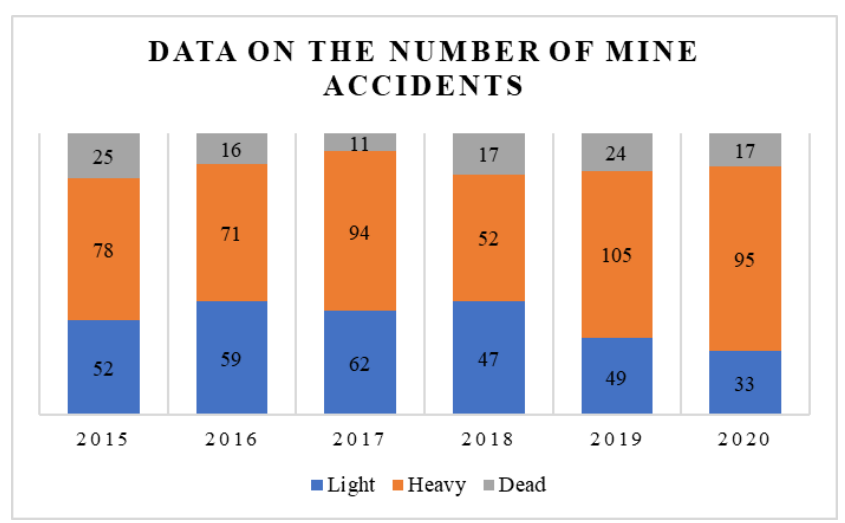

Figure 4. Data on the Number of Mine Accidents
Figure 5 shows the exposure delivered by the Directorate General of Minerals and Coal, which conveyed data on the number of deaths due to mining activities in 2019. The data that died was categorized based on commodities, types of permits and work experience. Based on the type of commodity, the number of percentages died in the largest mining activities occurred in mineral commodities at $62 \%$, while in coal commodities as much as $38 \%$. Based on the type of permit, the most in the contracting company is $79 \%$, then occurs in the owner's company as much as $17 \%$ and for sub contractor service companies as much as $4 \%$. Based on work experience divided into 3 criteria, namely 0 to 3 years as much as 5\%, 3 to 5 years as much as $30 \%$ and those over 5 years as much as $13 \%$.

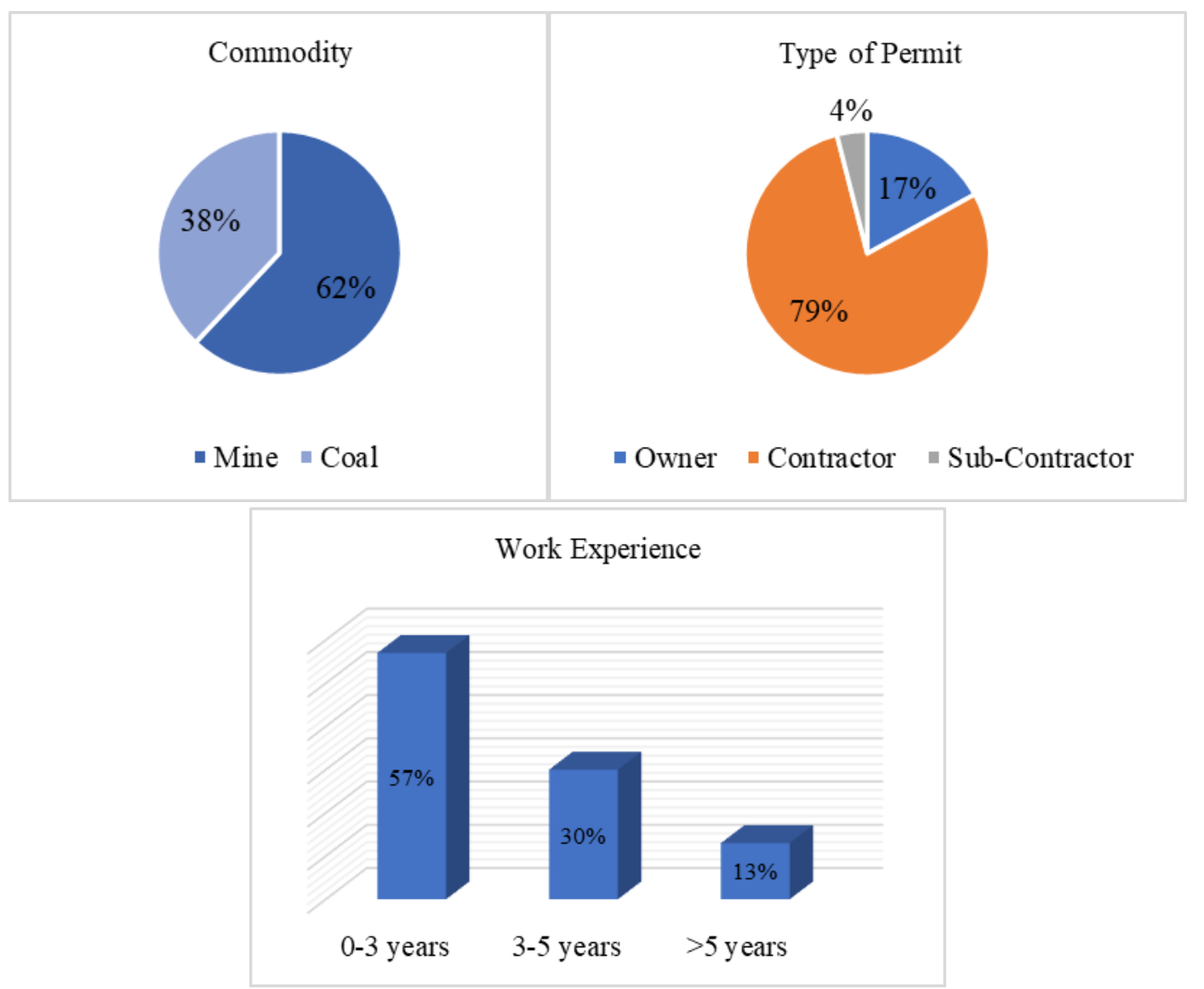

Figure 5. Distribution of Accident Data Died in 2019 
The last material delivered was the application of 5S (Seiri, Seiton, Seiso, Seiketsu and Shitsuke) and Hourensou. This material is delivered because it is considered important for companies with the hope that through the implementation of $5 \mathrm{~S}$ and $1 \mathrm{H}$ this can improve performance in the company by doing timely work with maximum results. In Indonesian $5 \mathrm{~S}$ is known as 5R, namely Ringkas, Rapi, Resik, Rawat dan Rajin. While Hourensou is interpreted as $\mathrm{Hou}$ for houkoku which means report; Ren for renraku which means inform; and Sou for soudan which means consultation. In addition to providing theories of $5 \mathrm{~S}$ and $1 \mathrm{H}$, there are also examples of application applications in several places such as companies engaged in recycling (Nur, 2016), transportation companies (Sugiharto et al., 2019) and even mining companies (Prawira et al., 2018).

The discussion activity was the last activity carried out at this CS activity session. The discussion went very effectively and there was enthusiasm shown by the participants. Participants generally ask related to awakening OHS culture in themselves. Conveyed to the participants that the main effort is to start from a small environment first, starting from home and then being used as a culture. In addition, it must also start from ourselves, if everyone has cultivated OHS, then health and safety for us is maintained and also for other co-workers, thus ensuring mining operations.

\section{Conclusion}

Based on the exposure that has been submitted above, it can be concluded some of the following:

1. Community Service activities for industries that are aligned with their areas of competence are felt to be very useful, because it can provide refreshment for employees and companies in the field.
2. All employees in PAS Company is a participant of this CS activity and follows and conducts very intensive and interactive discussions.

3. Cooperation between industry and university must continue to be improved, not only through CS activities, it can also be done with other activities, such as field visits and practices for students and joint research.

4. Leaders and employees are very grateful for this CS activity, because with this activity, there is a refresher about the importance of OHS for employees and company leaders.

\section{Acknowledgment}

With the implementation of CS activities in PAS Company, the team expressed its gratitude to Trisakti University for financing this activity, to the Department of Mining Engineering and the Faculty of Earth and Energy Technology for the support that has been given and to PAS Company has given the CS team the opportunity to do this activity and there is a flexibility to discuss and share experiences.

\section{References}

Atmaja, G. D., \& Palimbong, Y. (2020). Kajian Keselamatan dan Kesehatan Kerja (K3) pada Area Pengolahan Batu Andesit di PT. Niat Karya di Kecamatan Utan Kabupaten Sumbawa Besar. Jurnal Ulul Albab, 24(1), 8.

Direktorat Teknik dan Lingkungan Ditjen Minerba. (2020). Safety and Health Performance in Mining Industry. Webinar Best Practices: Mine Safety Performances PPSDM GeoMinerba. Bandung.

Ditjen MINERBA. (2019). Keputusan Direktur Jenderal Mineral dan Batubara No. 185.K/37.04/DJB/2019. Petunjuk Teknik Pelaksanaan Keselamatan Pertambangan dan Pelaksanaan, Penilaian, dan Pelaporan Sistem Manajemen Keselamatan Pertambangan Mineral dan 
Batubara. Kementerian Energi Sumber

Daya Mineral. Jakarta.

Kementerian ESDM. (2018). Peraturan Menteri

ESDM Nomor 26 Tahun 2018.

Pelaksanaan Kaidah Pertambangan Yang

Baik Dan Pengawasan Pertambangan

Mineral Dan Batubara. Jakarta.

Nur, M. (2016). Analisa Lingkungan Kerja dan

Program Kesehatan dan Keselamatan

Kerja Menggunakan Metode 5S (Studi

Kasus: PT. Gemilang Artha Prima Lestari

Rimbo Panjang, Kampar). Jurnal Teknik

Industri: Jurnal Hasil Penelitian dan

Karya Ilmiah dalam Bidang Teknik

Industri, $\quad 2(2), \quad 187$.

https://doi.org/10.24014/jti.v2i2.5103

Occupational Health and Safety Management

Systems. (2007). OHSAS 18001—Sistem

Manajemen Keselamatan dan Kesehatan

Kerja.

Prakoso, S., Maulani, M., Nugrahanti, A., Samura, L., \& Irham, S. (2021).
Sosialisasi Program Keselamatan dan

Kesehatan Kerja bagi Karyawan CV Rumah Kampung, Sawangan, Depok, Jawa Barat. Jurnal Abdi Masyarakat Indonesia, 3(1), 40-45.

Prawira, A. Y., Rahayu, Y., Hamsal, M., \& Purba, H. H. (2018). A Case Study: How 5S Implementation Improves Productivity of Heavy Equipment in Mining Industry. Independent Journal of Management \& Production, $\quad 9(4), \quad 1184$. https://doi.org/10.14807/ijmp.v9i4.826

Sugiharto, S., Tea, R., \& Jamhari, S. (2019). Evaluasi Penerapan Seiri, Seiton, Seiso, Seiketsu, Dan Shitsuke (5S) Pada Departemen Transportasi PT. Prasadha Pamunah Limbah Indrustri Bogor. Jurnal Keselamatan Transportasi Jalan (Indonesian Journal of Road Safety), 6(2), 88-109.

https://doi.org/10.46447/ktj.v6i2.34 